October 15,1993

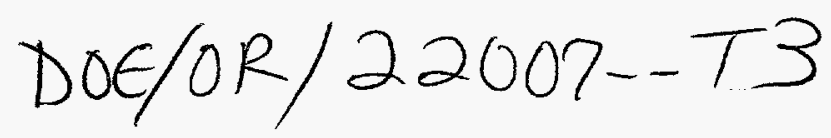

Mr. Robert B. Cook

Oak Ridge National Laboratory

Clinch River ER Program

P.O. Box 2008

Oak Ridge, Tennessee 37831

Dear Bob:

Please find enclosed two reports. The first entitled, "TVA

Sediment-Disturbing Activities within the Watts Bar Reservoir and Melton

Hill Reservoir Areas of the Clinch River" is the contract deliverable for

Task 5, of the project TVA is performing in support of the Cinch River Environmental Restoration Program. This report, which is in the form of a technical memorandum, identifies areas where potentially contaminated sediments have been deposited. If you have any questions or require additional information, please let me know.

The second enclosed report entitled, "Suspended-Sediment Inflows to Watts

Bar Reservoir" is a portion of the contract deliverable for Task 3, of the aforementioned project. Again, if you have any questions regarding this report, please give me a call or you may also contact Loyd Ewing at (615) 494-1940.

Sincerely,

Jack D. Milligan

Environmental Engineer

Water Management

JDM: CHV

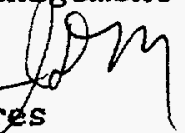

DISTAREUTION OF THIS DOCUMENT IS UAMATHA

cc: V. Alavian, $L A B$ 1A-N

L. M. Beard, GRN $2 F-K$

L. K. Ewing, LAB $1 \mathrm{~A}-\mathrm{N}$

H. C. Jones HB 2C-C

R. J. Pryor, 10C-K

Files WM $2 \mathrm{C}-\mathrm{C}$

Prepared by Jack D. Milligan

WRC $0297 \mathrm{~J}$

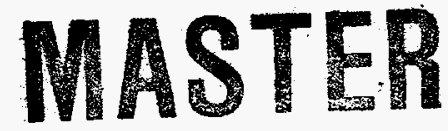

APPROVED FOR RELEASE OR PUBLICATION. INTEL. PROP. GP., OFC. OF CHIEF COUNSEL, DOE/ORO

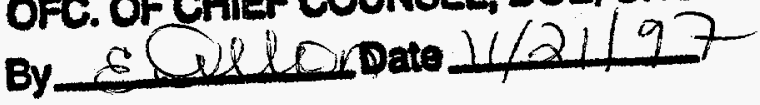




\section{DISCLAIMER}

This report was prepared as an account of work sponsored by an agency of the United States Government. Neither the United States Government nor any agency thereof, nor any of their employees, make any warranty, express or implied, or assumes any legal liability or responsibility for the accuracy, completeness, or usefulness of any information, apparatus, product, or process disclosed, or represents that its use would not infringe privately owned rights. Reference herein to any specific commercial product, process, or service by trade name, trademark, manufacturer, or otherwise does not necessarily constitute or imply its endorsement, recommendation, or favoring by the United States Government or any agency thereof. The views and opinions of authors expressed herein do not necessarily state or reflect those of the United States Government or any agency thereof. 


\section{DISCLAIMER}

Portions of this document may be illegible electronic image products. Images are produced from the best available original document. 


\author{
TENNESSEE VALIEY AUTHORITY \\ RESOURCE GROUP, ENGINEERING SERVICES \\ HYDRAULIC ENGINEERING
}

TECHNICAL MEMORANDUM

\title{
TASK 5: TVA SEDIMENT-DISTURBING ACTIVITIES WITHIN THE WATTS BAR RESERVOIR AND MELTON HILL RESERVOIR AREAS OF THE CLINCH RIVER
}

The objectives of Task 5 of the Interagency Agreement No. DE-AI05-910R22007 were to review: (1) the extent of dredging, construction, and other sediment-disturbing activities conducted by the Tennessee Valley Authority (TVA) in potentially contaminated areas of Watts Bar Reservoir; and (2) the disposition of the materials from these activities. This memorandum is the final report for Task 5 .

This memorandum describes major activities in the Watts Bar Reservoir and Melton Hill Reservoir areas of the Clinch River that possibly resulted in significant disturbance of potentially contaminated sediments. TVA records from the construction of Watts Bar Dam, Kingston Fossil Plant, and Melton Hill Dam were reviewed to facilitate qualitative description of the effect of these activities in disturbing potentially contaminated sediments. The critical period for these activities in disturbing contaminated sediments was during or after 1956 when the peak releases of radioactive contaminants occurred from the Oak Ridge Reservation.

\section{Watts Bar Dam Project}

Construction of Watts Bar Dam, located at Tennessee River Mile (TRM) 529.9, was completed in January 1942. Prior to completion of Watts Bar Dam, only minor, isolated, disconnected navigation improvements at some of the more hazardous navigation points in the shoal waters near Lenoir City were made (TVA, 1949). While construction activities did not affect contaminated sediments, Watts Bar Dam continues to hinder the downstream movement of contaminated sediments.

\section{Kingston Fossil Plant Construction}

Kingston Fossil Plant is located in the Ridge and Valley Province of the Appalachian Highlands, one and one-half miles due north of the town of Kingston, Tennessee (Bensiger and Kellberg, 1951). The plant is situated on a peninsula formed by the Clinch and Emory Rivers at Clinch River Mile (CRM) 2.6, in eastern Tennessee. Both rivers surrounding the peninsula are in the backwaters of Watts Bar Dam.

On-site construction of Kingston Fossil Plant began in April 1951, and the final unit was placed in commercial operation in December 1955 (The Kingston Steam Plant, 1965). The location of the plant was selected in part due to considerations of condenser cooling water requirements. The cooling water enters the plant through an intake on the Emory River. The pumping station is located at the head of the 4,500-foot intake channel, which 
extends from the original streambed of the Emory River in the Swan Pond Embayment of Watts Bar Reservoir to the plant pumping station.

The intake channel was constructed through dredging and backfilling operations. Earth and shale were dredged from the intake channel adjacent to the pumping station to obtain a bottom elevation of 711 feet mean sea level (msl). A volume of 44,044 cubic yards of earth and unclassified material was excavated to form the intake channel entrance from the Swan Pond embayment of Emory River. Additionally, 13,841 cubic yards of backfill were deposited to form the intake channel. The intake channel was completed in November 1954.

The discharge channel of the plant extends into the Clinch River on the opposite side of the peninsula, four miles downstream from the intake channel entrance. The discharge channel was constructed by excavating 124,587 cubic yards of unclassified material and by depositing 101,779 cubic yards of backfill. Discharge channel construction was completed by July 1952.

A fixed skimmer wall and an underwater dam were constructed in 1955 to improve the availability of cool water for the condensers. A dike was constructed across a portion of the Swan Pond embayment, from the intake channel to the Emory River, to channel the cold water flowing along the bottom of the Clinch River into the Emory River and then into the intake channel. A submerged dike or dam was subsequently built across the Clinch River downstream from the mouth of the Emory River to create a cool-water pool and increase the amount of cold water reaching the condensers.

The underwater dam was constructed in the fall of 1955 at CRM 3.9. The dam was constructed using approximately 17,000 tons of quarry-run limestone rock purchased from a local supplier and dumped from barges into position. The dam's 6-foot wide crest elevation was set at 722 feet to allow for navigation clearance during low water periods (13 feet below minimum pool elevation). A low point of the original river channel cross section, at about elevation 701.5 feet, required a maximum height of fill of 20.5 feet to the crest of the dam. The slope of the dam varies from 1:1 to 1.5:1, with an average slope of 1.25:1. Therefore, the submerged dam has functioned as a trap of some of the possibly contaminated sediments.

\section{Melton Hill Dam Project}

Melton Hill Dam is located on the Clinch River, in east Tennessee, 23.1 miles upstream from where the Clinch River enters the Tennessee River. The dam is located nine miles south of Oak Ridge. Melton Hill Dam with its navigation lock serves to extend the 9foot deep navigable channel of the Tennessee River up the Clinch River about 38 miles. The project is operated primarily to produce electrical power for peak energy demands during the weekday, with refilling of the reservoir during the weekend. Construction of the project began in September 1960 (The Melton Hill Project, 1966).

Various construction activities were important to review for Task 5. Extensive excavation was required for several project facilities, e.g., lock, spillway, powerhouse, dam foundation, river diversion channel, and dikes. Dredging of navigation channels around Jones Island and Grubb Island was performed for the river reach from CRM 18.3 to the dam at 
CRM 23.1. Also, both Gallaher Bridge (CRM 14.5) and White Wing Bridge (CRM 21.7; replaced with Vanden Bulck Bridge) were replaced to allow for navigation.

Excavation for Project Facilities-Excavation involved the removal of overburden and rock for the various permanent structures (Table 1). Excavated volume totaled 284,000 cubic yards, of which 105,000 cubic yards was classified as rock. The bedrock at the project site is Knox dolomite of Cambrian Age. Rock outcrops were present on the right abutment and had very little overburden. The river channel had only small pockets of sand and gravel on the rock surface. The left floodplain had about 30 feet of alluvial overburden consisting generally of fine-grained residual soils.

Much of the excavation was required to remove unsuitable materials for the lock, spillway, and dam foundations. The rock at the right abutment, the upper end of the lock and spillway, required little treatment except for the installation of an upstream grout curtain. The downstream portion of the lock had serious weathering and clay-filled seams along nearvertical joints and nearly level bedding planes, requiring several feet rock excavation. A wide, earth-filled solution channel, which extended downstream into the draft tube excavation, was found under the powerhouse intake. Also, the left non-overflow dam foundation had clay-filled vertical solution channels ranging to a foot or more in width and clay-filled bedding seams. Therefore, several feet of rock were excavated, the opened seams were cleaned out, and then were filled with concrete and pressure grouted. The rock at the sides of the channel was badly weathered and jointed, requiring extensive excavation. Excavated material was hauled to upstream spoil areas.

\begin{tabular}{||l|c|c|}
\hline \multicolumn{3}{|c|}{ TABLE 1 } \\
\multicolumn{3}{|c|}{$\begin{array}{c}\text { Melton Hill Dam } \\
\text { Excavation Quantities }\end{array}$} \\
\hline \multicolumn{1}{|c|}{ Feature } & Earth, cubic yards & Rock, cubic yards \\
\hline Lock Structure & 52,700 & 47,100 \\
\hline Dam and Spillway & 18,600 & 11,500 \\
\hline Powerhouse & 16,300 & 26,900 \\
\hline Forebay & 19,800 & 8,800 \\
\hline Tailrace & 60,000 & 5,700 \\
\hline $\begin{array}{l}\text { Channel Improvements } \\
\text { (1st stage) }\end{array}$ & 8,500 & 4,700 \\
\hline Intake & 3,800 & 104,700 \\
\hline \hline \multicolumn{1}{|c|}{ TOTAL } & 179,700 & - \\
\hline
\end{tabular}


Excavation of an 1,800-foot long by 60 -foot wide river diversion channel through the . left bank floodplain (looking downstream) was started in December 1960, and completed in May 1961. Excavated material was hauled to a spoil area on the upstream left bank. The total volume of earth excavated was 224,000 cubic yards. Rock was encountered about 3 feet above the designed channel bottom of 727 feet, which required the removal of 9,000 cubic yards of rock. This rock, together with a small purchased quantity, was used on the channel slopes for protection. Dikes were also constructed from the north bank starting at points 500 feet upstream and 1,100 feet downstream from the dam axis. Purchased quarry-run rock and excavated rock from the construction of the aggregate haul road were used as fill.

There were two general types of fill used on this project. Type A consisted of carefully selected and compacted clay taken from two principle borrow areas: Area No. 1, the parking area on the south bank west of the Oak Ridge Hospital; and Area No. 2, the hillside south of the left abutment. Type B fill was a common fill of unclassified material obtained when excavating for the various project structures. The fill quantities used are given in Table 2.

\begin{tabular}{|c|c|}
\hline \multicolumn{2}{|c|}{$\begin{array}{c}\text { TABLE } 2 \\
\text { Melton Hill Dam } \\
\text { Fill and Backfill }\end{array}$} \\
\hline Location & Quantity, cubic yards \\
\hline Lock & 17,340 \\
\hline Concrete Dam and Spillway & 21,950 \\
\hline Powerhouse & 3,100 \\
\hline Diversion Channel & 74,740 \\
\hline General Yard (right bank) & 58,560 \\
\hline General Yard (left bank) & 60,660 \\
\hline Switchyard & 20,460 \\
\hline TOTAL & 256,810 \\
\hline
\end{tabular}

Backfill along the right bank (lock and lower approach lands) consisted of excavated rock from the powerhouse. A clay fill was also used from borrow area No. 1. The left bank in the area downstream from the service bay near the river was Type A fill from borrow area No. 1. The switchyard area was also filled with type A material.

Downstream Channel Dredging-Dredging was required in Watts Bar Reservoir at Grubb Island, Jones Island, and immediately downstream of Melton Hill Lock. Channel work 
started at Clinch River Mile 18.2 and affected approximately 3.2 miles of the 4.8 miles to the upstream lock location. Over 351,600 cubic yards of material was dredged from the channel above Elevation 723.0 feet msl (1 foot below design depth) and about 104,000 cubic yards of material was removed from below that elevation (Table 3).

\begin{tabular}{|c|c|c|c|}
\hline \multicolumn{4}{|c|}{$\begin{array}{c}\text { Melton Hill Dam } \\
\text { Downstream Dredged Quantities }\end{array}$} \\
\hline Location & $\begin{array}{l}\text { Suction } \\
\text { Dredge, } \\
\text { Cubic Yards }\end{array}$ & $\begin{array}{c}\text { Dipper } \\
\text { Dredge, } \\
\text { Cubic Yards } \\
\end{array}$ & $\begin{array}{c}\text { Total } \\
\text { Quantity, } \\
\text { Cubic Yards }\end{array}$ \\
\hline Grubb Island Area (CRM 18.2 to 18.8 ) & 83,700 & & 83,700 \\
\hline $\begin{array}{l}\text { Jones Island Area (CRM } 19.5 \text { to 20.8) } \\
\text { Rock } \\
\text { Overburden } \\
\text { Subtotal } \\
\end{array}$ & 24,100 & $\begin{array}{l}27,600 \\
77,300\end{array}$ & 129,000 \\
\hline $\begin{array}{l}\text { Lock Approach Area (CRM } 21.7 \text { to 23.0) } \\
\text { Rock } \\
\text { Overburden } \\
\text { Subtotal } \\
\end{array}$ & & $\begin{array}{l}81,000 \\
57,500\end{array}$ & 138,500 \\
\hline Other Areas & & & 104,400 \\
\hline $\begin{array}{l}\text { Total Volume Dredged } \\
\text { Above Elevation } 723.0 \mathrm{ft} . \\
\text { Below Elevation } 723.0 \mathrm{ft} .\end{array}$ & & & $\begin{array}{l}351,600 \\
104,000\end{array}$ \\
\hline
\end{tabular}

Dredging in the Grubb Island area (CRM 18.2 to 18.8) began in October 1962 and lasted for about 6 months. A 12-inch suction dredge was used during this period. Dredged material consisting of silt, sand, and gravel was deposited on Grubb Island and nearby islands to the southwest, southeast, and east (Table 4). The suction dredge was then used for a period of two months in the Jones Island area (CRM 19.5 to 20.8). The suction dredge removed approximately 83,700 cubic yards of material in the Grubb Island area and 24,100 cubic yards of material in the Jones Island area.

A dipper dredge was used briefly in November 1962 in the Grubb Island area to clear the channel of loose rocks that could not be handled by the suction dredge. Spoil was deposited in deep areas of the river and on the riverbanks. The dredge was then moved to the lock approach area (CRM 21.7 to 23.0) to remove the broken rock that had resulted from drilling and blasting. Approximately 34,600 cubic yards of rock dredged from the lock 
approach area was used as riprap on the right bank downstream of the lock. Some dredge material was wasted along the left bank and some was barged to the upstream edge of Jones Island (Table 4). The dipper dredge removed approximately 81,000 cubic yards of rock and 57,500 cubic yards of overburden in the lock approach area, and 27,600 cubic yards of rock and 77,300 cubic yards of overburden in the Jones Island area.

Dredged materials were deposited at identified sites near to where they were excavated (Table 4). Approximately 90,200 cubic yards of dredged materials were deposited around Grubb Island. Approximately 104,900 cubic yards of dredged material were deposited on Jones Island. Also, approximately 83,000 cubic yards of dredged material were deposited along the Clinch River banks between Melton Hill Dam and the Vanden Bulck Bridge (Highway 95). By including approximately 34,600 cubic yards of dredged rock used as riprap in the lock approach area, the total spoil volume accounted for is 312,700 cubic yards. Therefore, approximately 142,900 cubic yards of potentially contaminated dredged materials have not been accounted for.

\section{Summary}

The key to the effect of the construction activities of the three projects, Watts Bar Dam, Kingston Fossil Plant, and Melton Hill Dam, in disturbing possibly contaminated sediments is the 1956 date of peak releases of contaminants from the Oak Ridge Reservation. Since construction of Watts Bar Dam and Kingston Fossil Plant occurred prior to 1956, only minimal disturbance of contaminated sediment occurred. However, Watts Bar Dam and the submerged dam near Kingston Fossil Plant could hinder subsequent movements of contaminated sediments.

Construction of Melton Hill Dam and the associated channel dredging may have had a significant effect in disturbing possibly contaminated sediments, since these activities occurred beginning in 1960. Channel dredging in the Jones Island and Grubb Island areas was directly downstream from the White Oak Creek confluence with the Clinch River. Therefore, the over 200,000 cubic yards of dredged material (Table 3) may have been contaminated by releases from White Oak Creek.

For the most part, the excavated material was deposited as spoil in the same general vicinity in which it was excavated. However, construction estimates of the volume of dredged materials placed in spoil areas did not account for approximately 30 percent of the potentially contaminated materials. 


\begin{tabular}{|c|c|c|}
\hline \multicolumn{3}{|c|}{$\begin{array}{c}\text { TABLE } 4 \\
\text { Dredged Spoil Areas } \\
\text { Location and Quantity }\end{array}$} \\
\hline Description $^{1}$ & Location Coordinates ${ }^{2}$ & $\begin{array}{l}\text { Quantity } \\
\text { cubic yards }\end{array}$ \\
\hline \multicolumn{3}{|l|}{ A. Grubb Island Area (CRM 18.2 to 18.8 ) } \\
\hline $\begin{array}{l}\text { 1) Area along the left (south) bank of } \\
\text { Watts Bar Reservoir channel on south } \\
\text { side of Grubb Island. }\end{array}$ & $\begin{array}{l}2,483,500-2,484,000 \mathrm{E}: \\
552,500 \mathrm{~N}\end{array}$ & $16,000+/-$ \\
\hline $\begin{array}{l}\text { 2) Area along the south shore of Grubb } \\
\text { Island. }\end{array}$ & $\begin{array}{l}2,481,500-2,483,000 \mathrm{E}: \\
552,500-553,000 \mathrm{~N}\end{array}$ & $71,700+/-$ \\
\hline $\begin{array}{l}\text { 3) Area along the left (south) bank of } \\
\text { Watts Bar Reservoir channel on south } \\
\text { side of Grubb Island. }\end{array}$ & $\begin{array}{l}2,481,500-2,482,500 \mathrm{E}: \\
552,000-552,500 \mathrm{~N}\end{array}$ & $2,000+/-$ \\
\hline $\begin{array}{l}\text { 4) Area along the south shore of Grubb } \\
\text { Island. }\end{array}$ & $\begin{array}{l}2,481,500 \mathrm{E}: \\
552,000-552,500 \mathrm{~N}\end{array}$ & $500+\%$ \\
\hline \multicolumn{3}{|l|}{ B. Jones Island Area (CRM 19.5 to 20.8) } \\
\hline $\begin{array}{l}\text { 1) Area at the eastern (upstream) end } \\
\text { of Jones Island. }\end{array}$ & $\begin{array}{l}2,492,000-2,493,000 \mathrm{E}: \\
551,500-552,500 \mathrm{~N}\end{array}$ & $93,500+/-$ \\
\hline $\begin{array}{l}\text { 2) Area along the central region of the } \\
\text { north shore of Jones Island (left bank of } \\
\text { Watts Bar Reservoir channel). }\end{array}$ & $\begin{array}{l}2,490,500-2,491,500 \mathrm{E}: \\
553,000-553,500 \mathrm{~N}\end{array}$ & $8100+/-$ \\
\hline $\begin{array}{l}\text { 3) Area along the south shore of the } \\
\text { west end of Jones Island. }\end{array}$ & $\begin{array}{l}2,488,500-2,489,000 \mathrm{E}: \\
553,000 \mathrm{~N}\end{array}$ & $3300+/-$ \\
\hline
\end{tabular}

1 Descriptions of spoil areas were based on TVA/Melton Hill Project/River Channel Improvement construction drawings. Drawing for Grubb Island Area was number 11N801R3 (9/28/64). Drawings for Jones Island Area were numbers 11N701R3 (12/9/65) and 11N702R3 (12/9/65). Drawings for Lock Approach Area were numbers 11N601R4 (12/9/65), 11N602R5 (12/9/65), and 11N602AR2 (12/9/65).

${ }^{2}$. Coordinates are based on the Tennessee State System of Rectangular Coordinates with Base Line coordinates dated August 2, 1957.

${ }^{3}$ Deposited spoil quantities are estimates. 


\begin{tabular}{|c|c|c|}
\hline \multicolumn{3}{|c|}{$\begin{array}{l}\text { TABLE } 4 \text { (continued) } \\
\text { Dredged Spoil Areas } \\
\text { Location and Quantity } \\
\end{array}$} \\
\hline Description $^{1}$ & Location Coordinates ${ }^{2}$ & $\begin{array}{l}\text { Quantity } \\
\text { cubic yards }\end{array}$ \\
\hline \multicolumn{3}{|c|}{ C. Lock Approach Area (CRM 21.7 to 23.0 ) } \\
\hline $\begin{array}{l}\text { 1) Area along the left (south) bank of } \\
\text { the Clinch River approximately } 2600 \\
\text { feet downstream from Melton Hill Dam. }\end{array}$ & $\begin{array}{l}2,500,000-2,502,000 \mathrm{E}: \\
548,000-549,000 \mathrm{~N}\end{array}$ & $83,000+/-$ \\
\hline $\begin{array}{l}\text { 2) Area along the right (north) bank of } \\
\text { the Clinch River approximately } 1800 \\
\text { feet upstream from the Vanden Bulck } \\
\text { Bridge (Highway 95). }\end{array}$ & $\begin{array}{l}2,498,000 \mathrm{E}: \\
548,000-549,000 \mathrm{~N}\end{array}$ & - \\
\hline $\begin{array}{l}\text { 3) Area along the right (north) bank of } \\
\text { the Clinch River approximately } 600 \text { feet } \\
\text { upstream from the Vanden Bulck } \\
\text { Bridge. }\end{array}$ & $\begin{array}{l}2,497,000 \mathrm{E}: \\
548,000-549,000 \mathrm{~N}\end{array}$ & -- \\
\hline \multicolumn{2}{|l|}{ Total Spoil Volume } & $278,100+/-$ \\
\hline
\end{tabular}

\section{ADDITIONAL NOTE}

\section{Interagency Agreement - Watts Bar Reservoir Permit Coordination}

Copies of Section 26a approvals issued by TVA that may have involved dredging are not included in this report. These documents have been previously transmitted under separate cover (Pryor, 1992). That information was part of an Interagency Agreement - Watts Bar Reservoir Permit Coordination between the Tennessee Valley Authority, U.S. Army Corps of Engineers, Department of Energy, Environmental Protection Agency, and Tennessee Department of Health and Environment. The purpose of the agreement was to establish a procedure for future interagency coordination and review of permitting and other use authorization activities by the Corps of Engineers and TVA which could result in the disturbance, re-suspension, removal and/or disposal of contaminated sediments or potentially contaminated sediments in Watts Bar Reservoir. Specific actions were categorized as having No Significant Sediment Disturbance (NSSD), Marginal Sediment Disturbance (MSD), or Potential Major Sediment Disturbance (PMSD). 


\section{REFERENCES}

Bensiger, C. P., and J. M. Kellberg, 1951, "Preliminary Geological Investigations for Eastern Area Steam Plant," Division of Water Control Planning, Geological Branch, Tennessee Valley Authority, Knoxville, Tennessee.

The Kingston Steam Plant, 1965, Technical Report No. 34, Tennessee Valley Authority, Knoxville, Tennessee.

Letter from Robert Pryor, Water Resources, to Bob Cook, Martin Marietta Energy Systems, September 2, 1992.

The Melton Hill Project, 1966, Technical Report No. 15, Tennessee Valley Authority, Knoxville, Tennessee.

The Tennessee River Navigation System: History, Development, and Operation, 1964, Technical Report No. 25, Tennessee Valley Authority, Knoxville, Tennessee.

The Watts Bar Project, 1949, Technical Report No. 9, Tennessee Valley Authority, Knoxville, Tennessee.

Prepared by

Loyd K Ewing and Lisa M. Beard

Engineering Laboratory

Norris, Tennessee

September 1993

cc: Files, LAB 1A-N 